\title{
How Do African States Think about Cultural Property? Re-Visiting Management Elites in Southern Africa
}

\section{Rachel King*}

\begin{abstract}
This article addresses a methodological lacuna in studies of African cultural property: states are rarely subjected to the same detailed ethnographic enquiry as communities local to heritage sites. I argue that this is the result of historical circumstances and disciplinary trends treating states as nebulous "up there" entities distinct from the grassroots—and, thus, subject to different modes of enquiry. I demonstrate a corrective approach through a historical ethnographic examination of the government of Lesotho's archives, examining a period from 1991 to 1993 that saw early efforts to create a national monument at Thaba Bosiu. This detailed view reveals habits of thinking about heritage among bureaucrat-intellectuals, administrators, and international consultants. It offers new insights into how state actors articulated visions for new industries, public participation, and spirituality in public life as well as how to demonstrate incapacity to secure future development funds.
\end{abstract}

\section{INTRODUCTION}

Especially in sub-Saharan Africa but also in other postcolonial contexts, heritage scholarship often does not examine how states think about cultural property. I am not referring to policy analyses (of which there are many) but, rather, to ethnographic observations, which feature so prominently in studies of the stakeholder communities that are most proximately or visibly related to heritage assets. By contrast, African states and their representatives often (but not always) escape this sort of attention, cast as monolithic entities that exist (in James Ferguson's words) "up there" above the grassroots.

\footnotetext{
${ }^{\star}$ Institute of Archaeology, University College London, United Kingdom; Rock Art Research Institute, University of the Witwatersrand, South Africa; Email: tcrnrki@ucl.ac.uk
}

ACKNOWLEDGMENTS: I thank the staff at the Lesotho National Archives for their assistance in conducting this research and Stephen Gill for clarifying points regarding the 'Moho Museum. 
There are, of course, historical reasons for this situation, which can only be surveyed broadly here. Defining the state in Africa is fundamentally complicated by the ways in which political and sociocultural borders typically tracked the agendas of imperialist powers rather than emic ideas of nationhood and identity. The states that eventually emerged from the 1950s following decolonization had "the trappings of 'sovereignty,"” but their instruments for administering their new territories while also forging autonomous links with the outside world were burdened or weakened by colonial legacies. ${ }^{1}$ Ultimately, the imposition of structural adjustment programs on African states in the late twentieth century resulted in government functions being outsourced to new forms of (putative) civil society, producing states that were directed to do things other than govern. ${ }^{2}$

Many post-independence states (the subjects of this article) were inheritors of legislation and management frameworks that excluded the voices of communities local to heritage sites-frameworks that were often not extensively revised under successive governmental administrations. While African heritage places may be distinct from Western ones because people have often dwelt in them for generations, ${ }^{3}$ Webber Ndoro has described a widespread "official failure" to recognize that this dwelling constituted a form of management. ${ }^{4}$ Some governments (for example, Botswana and South Africa) have taken steps to include public participation in their revised management policies, but, in the aggregate, heritage practitioners in Africa describe the emergence of a "heritage management elite whose values are rather different from the population at large." 5 This elite is further buttressed by international heritage conservation conventions and frameworks (for example, the Venice Charter and the World Heritage Convention) that view management as a top-down effort, although this trend may be abating. ${ }^{6}$

The emphasis in current heritage studies on local participation and indigenous knowledge, then, appears both logical and necessary. Logical because communities with a long history of occupying heritage places have always known how to manage them. Necessary because of the critical literature illustrating the violence (socioeconomic and epistemic) that is done when indigenous knowledge is suppressed by management elites and their policies. States, though, are rendered as non-communities; they are not seen as creators of indigenous knowledge about managing cultural properties. Neoliberalized states, in particular, appear so overburdened with management apparatuses, not to mention a heavily enriched

\footnotetext{
${ }^{1}$ Cooper 2002, 5.

${ }^{2}$ Ferguson 2006, 38.

${ }^{3}$ Keitumetse, Matlapeng, and Monamo 2007.

${ }^{4}$ Ndoro 2003, 81.

${ }^{5}$ Ndoro and Pwiti 2004, 155.

${ }^{6}$ Jopela 2017, 3. International Charter for the Conservation and Restoration of Monuments and Sites, 31 May 1964, http://icomos.org/charters/venice_e.pdf (accessed 5 August 2019); Convention Concerning the Protection of the World Cultural and Natural Heritage, 23 November 1972, 1037 UNTS 151.
} 
bureaucratic bourgeoisie, that they struggle to take local (often rural) perspectives seriously. This view is reaffirmed by the trend in anthropological heritage studies to privilege a focus on the local—with all of its textures and heterogeneity-over the national. In existing heritage literature (especially pertaining to Africa, as detailed below), elites are typically drawn in contrast to local communities, implying that once a person or group enters into an arrangement with state, parastatal, or transnational bureaucracy they become more elite than local or cease being local altogether. Conversely, attention to national or governmental histories of heritage management has often been the remit of historians, who examine museums or commodified forms of heritage to consider how these manifested the power and vision of various political constituencies. ${ }^{7}$

In this article, I propose something different, aligned to the position that "states may be better viewed not in opposition to society but as bundles of social practices that are every bit as local in their social situatedness as any other." ${ }^{\prime \prime}$ argue that governing entities can be places where we see indigenous knowledge and epistemologies about cultural property articulated and negotiated. I want to explore where we can gain greater insight into how state expertise and authority over heritage was constituted—and forced to justify itself—by going deeper into the inner workings of state bodies and individual actors. Lynn Meskell's recent work has underscored how bureaucracies and individual aspirations impact heritage knowledge and policy; ${ }^{9}$ this is true both for international bodies like the United Nations Educational, Scientific and Cultural Organization (UNESCO) and for national institutions.

Of course, government elites have the power to create agendas that actively antagonize other heritage stakeholders; I do not propose an equivalency between state actors and communities local to heritage places. I argue (in line with anthropologies of governance) that the "up there" power of heritage management elites in government is not something taken for granted; it must be performed. I am especially interested in where this constitution of authority is non-discursive-where it occurs primarily within governing institutions rather than in the public sphere.

I demonstrate these points through a historical ethnographic exploration of the government of Lesotho's attempts to craft a management strategy for one heritage site from 1991 to 1993: the national monument and past home of the nation's progenitor Moshoeshoe I at Thaba Bosiu (Figure 1). Drawing on government archives, I describe how a core group of bureaucrat-intellectuals, administrators, and international consultants - the elites that I consider-debated how to create a new heritage tourism industry around Basotho values, the role of community consultation in site management, and how to demonstrate incapacity to international funders. My discussion illustrates a need to relate histories of heritage

\footnotetext{
${ }^{7}$ Peterson 2015.

${ }^{8}$ Ferguson 2006, 99.

${ }^{9}$ Meskell 2018.
} 


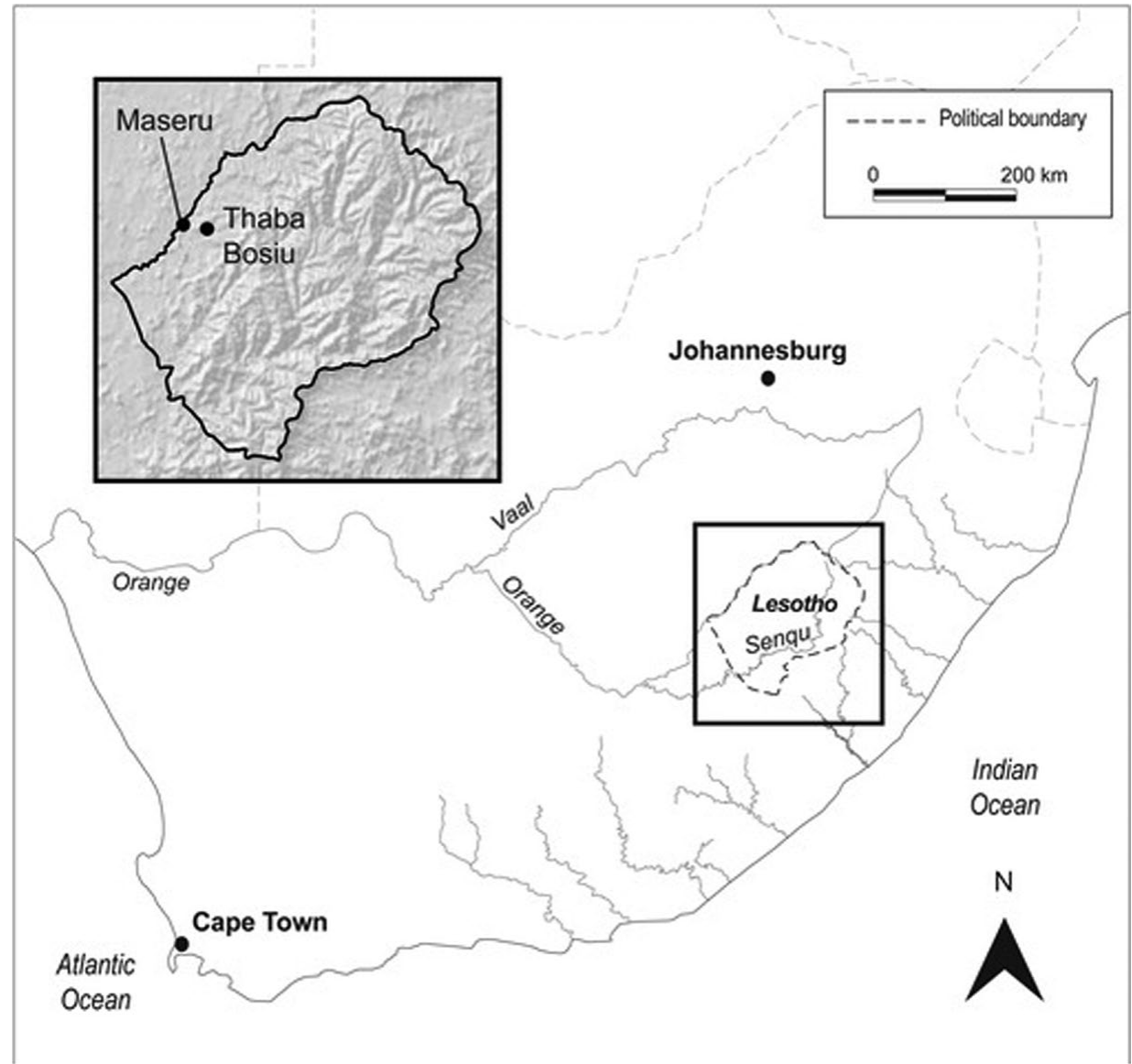

Figure 1. Locator map showing Thaba Bosiu. Map created using ArcGIS ${ }^{\circledR}$ software by Esri (ArcGIS ${ }^{\circledR}$ and ArcMap $^{\mathrm{TM}}$ are the intellectual property of Esri and are used herein under license; Copyright (C) Esri. All rights reserved).

management to histories of governance and international development, while following how logics of heritage emerged over time and within the cultures of governing institutions. ${ }^{10}$

Accessing state archives is not always possible and critiquing state activities carries risks for scholars, with different stakes for local and foreign researchers; my approach is not universally available. Where possible, though, we should take the opportunity to reflect on where a focus on extra-state entities and the grassroots is a product of the same neoliberalisms that we critique in our scholarship. ${ }^{11} \mathrm{We}$ should ask, in other words, how has heritage scholarship helped to imagine states as non-communities?

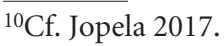

${ }^{11}$ Cf. Chalfin 2010, 4.
} 


\section{STATES AS NON-COMMUNITIES}

It is useful to begin by examining the ways in which our conception of how African states make knowledge about heritage is constrained by a suite of historical circumstances and politico-economic policies, and by our own methodological inclinations. In much of sub-Saharan Africa, heritage management did not start with colonizers, but many institutionalized mechanisms are colonial inheritances. Ndoro argues that the devolution of heritage management authority to governments and associated institutions is itself a colonial artifact. ${ }^{12}$ Although communities living at or near heritage places may have been custodians of these sites for generations (and possessed elites of their own), where colonial heritage legislation existed, this entrusted museums, universities, and governments with a "mandate to preserve and present" heritage. ${ }^{13}$ In settler colonial contexts like Kenya, South Africa, and Rhodesia (Zimbabwe), heritage management became the preserve of a class of mercantilists and bureaucrats_-for instance, managing Great Zimbabwe was the specific province of purpose-built bodies in Rhodesia from 1902. ${ }^{14}$ Heritage sites became government property, associated with a constellation of laws aimed at suppressing African cultural activity. ${ }^{15}$

Once they were independent, some states (for example, Chad, Malawi, Lesotho, Angola) adopted new heritage legislation, while, in most cases, colonial laws were updated but allowed to persist. ${ }^{16} \mathrm{New}$ governments intent on consolidating authority invested heavily in monumental heritage, adapting architectural styles from the West and from socialist states like North Korea, the latter constituting an element of Cold War diplomacy. ${ }^{17}$ However, the socialism that marked many African states' transition from liberation struggle to independence did not lead to the inclusion of local communities in heritage management. ${ }^{18}$ Instead, the general trend was that management authority remained "up there," vested in a new cadre of bureaucratic heritage elites that was contoured to the politics of the postindependence era. Cultural property significant to smaller, more local constituencies was minimized or disregarded in the face of monumental landscapes and efforts to build new national identities.

Ndoro and Gilbert Pwiti suggest a straight line from colonial infrastructure to the post-independence influence of UNESCO's 1972 World Heritage Convention in Africa: ${ }^{19}$ the incomplete dismantling of earlier legislative frameworks and the Convention's promulgation of top-down, government-led management allowed

\footnotetext{
${ }^{12}$ Ndoro 2003, 81.

${ }^{13}$ Ndoro and Pwiti 2004, 156.

${ }^{14}$ Chirikure, Ndoro, and Deacon 2018.

${ }^{15}$ Ndoro and Pwiti 2004, 156-57.

${ }^{16}$ Jopela 2017, 136-37.

${ }^{17}$ Jopela 2017, 112-13, 123.

${ }^{18}$ Chirikure et al. 2018.

${ }^{19}$ Ndoro and Pwiti 2004, 155.
} 
Western heritage theories and practices to continue to reign, co-opting a bureaucratic management class with an entrenched interest in holding onto authority. Susan Keitumetse has highlighted how the World Heritage Convention facilitated an enshrined distinction between states parties as signatories and local communities as participators, not agenda setters. ${ }^{20}$ While the Convention and other legal instruments (including, eventually, the 2003 Convention for the Safeguarding of Intangible Cultural Heritage [CSICH]) contain community participation principles affording opportunities for expressions of local agency, these are often lost in the technocratic processes within, for example, many of Botswana's state-led archaeological management practices. ${ }^{21}$ Albino Jopela further argues that the "domestication" of the World Heritage Convention in southern Africa has been marked by fissures within governing entities: ${ }^{22}$ nationalistic and domestic agendas set within the continent have clashed with guidance that UNESCO and its advisory bodies gave to states parties.

Later, state-led heritage discourses, such as liberation heritage, further tended to amplify divisions between state management elites and many publics. Within most (but not all) southern African countries, post-independence nation building reaffirmed a binary between newly empowered revolutionaries and reactionaries, and sanitized the histories of the "struggles within the liberation struggles." ${ }^{23}$ Jopela illustrates how this memory work took a further turn in Mozambique with the adoption (especially in the 1990s and early 2000s) of neoliberal policies, instigating a government-led strategy of "organised forgetting" to obliterate the earlier, Marxist-Leninist past. ${ }^{24}$ This process resonates with post-independence contexts (for example, in Zimbabwe) where state-led assaults on citizens were justified, suppressed, or rewritten as part of nationalistic heritage agendas.

The transition to neoliberalism and structural adjustment programs further cast states as non-communities, in that states were positioned in opposition to the grassroots and civil society. African states' engagement with neoliberal policies has been dated to the $1970 \mathrm{~s},{ }^{25}$ with the heyday of structural adjustment schemes occurring from the 1980 s to the 2000s. As mentioned above, these reforms aimed at rolling back states defined as non-functional or oppressive, creating new opportunities for democracy and economic growth by putting ever-more governing power in the hands of civil society organizations bolstered by international funding and expertise. Criticisms of these schemes are legion. African states became criminalized and "hollowed out" as their governing powers were outsourced, precipitating political crises. ${ }^{26}$ Economists belatedly became aware of a lack of consensus on what

\footnotetext{
$\overline{{ }^{20} \text { Keitumetse } 2014 .}$

${ }^{21}$ Keitumetse, Matlapeng, and Monamo 2007, 102, 107.

${ }^{22}$ Jopela 2017, 154-55.

${ }^{23}$ Jopela 2017, 195.

${ }^{24}$ Jopela 2017, 283.

${ }^{25}$ Chalfin 2010, 2.

${ }^{26}$ Bayart, Ellis, and Hibou 1999; Clapham 1996.
} 
constituted the "fundamentals" of development. ${ }^{27}$ A new transnational landscape emerged in which foreign investment coalesced in enclaves of money and power while skipping over swathes of the continent. ${ }^{28}$ To the extent that we still think of states as being "up there," this is now a "precarious achievement." 29

The United Nations' (UN) and UNESCO's legal instruments have tended to reinforce these configurations of governance. ${ }^{30}$ From the 1992 Rio Declaration to the 2030 Agenda for Sustainable Development, states parties were forced into partnerships with non-state entities to satisfy the conditions for the conservation of natural and cultural assets. ${ }^{31}$ Local communities, on the other hand, were cast as "storage" for indigenous knowledge. ${ }^{32}$ The devolution of neoliberal heritage management to extra-state actors, then, mirrored that of neoliberal governance. ${ }^{33}$ It also arguably expanded the world of heritage management elites to encompass this domain of non-governmental and civil society organizations that existed outside of government structures but was still subject to neoliberal regulation and development schemes. Rosemary Coombe, echoing Tania Murray Li, ${ }^{34}$ encourages us to utilize ethnographic tools to interrogate elements of these regimes, thereby illustrating the problems of misrepresenting the extent of state sovereignty.

This chimes with Anna Tsing's suggestion to reflect on how ethnographic modes of enquiry have helped to produce underdeveloped understandings of "up there" institutions. ${ }^{35}$ As so much of anthropological theory and praxis has focused on producing textured information about local subjects, state and global bodies often look more "blob-like" by contrast. In her ethnography of Ghanaian state bureaucracies, Brenda Chalfin suggests a corrective to these habits, noting that states have particular cultures and epistemologies that must be constantly reaffirmed and that these reaffirming practices are within the anthropologist's power to observe. ${ }^{36}$ This resonates with Ferguson and Akhil Gupta's insistence that states can think about their powers non-discursively: ${ }^{37}$ while they must publicly perform their "up there" position, state bureaucracies also work internally to develop their own habits and authority.

Heritage studies' views of modern African states as non-communities-not subject to the same enquiries about managing and theorizing cultural property as local

\footnotetext{
${ }^{27}$ Mkandawire and Soludo 2003.

${ }^{28}$ Ferguson and Gupta 2002.

${ }^{29}$ Ferguson 2006, 112.

${ }^{30}$ Meskell 2018, 114-17.

${ }^{31}$ Keitumetse 2016. Rio Declaration on Environment and Development, 12 August 1992, 31 ILM 874 (1992); Transforming Our World: The 2030 Agenda for Sustainable Development, 25 September 2015, https://sustainabledevelopment.un.org/content/documents/21252030\%20Agenda\%20for\%20 Sustainable\%20Development\%20web.pdf (accessed 5 August 2019).

${ }^{32}$ Keitumetse 2011.

${ }^{33}$ Coombe 2012, 378-79.

${ }^{34}$ Li 2007; Coombe 2012.

${ }^{35}$ Tsing 2001, 160.

${ }^{36}$ Chalfin 2010.

${ }^{37}$ Ferguson and Gupta 2002.
} 
communities-are conditioned by this combination of historical circumstances and disciplinary heuristics. A methodological lacuna has formed, leaving the cultures of heritage bureaucracies within African states under-theorized and understudied. Which brings me to this article's concern: if we view states as "bundles of practices" that are more local than meets the eye, can we observe states and their elites articulating heritage epistemologies and management sensibilities?

I take elites here to refer to the class of bureaucrats, intellectuals, and consultants that, in the structural adjustment period, constituted major administrative decision makers and policy influencers surrounding state-led and internationally funded heritage projects. Of course, non-state stakeholders practicing traditional forms of heritage management have (perhaps have always had) networks of elites and leaders that play significant roles in their communities and can also take on roles within government or parastatal structures, blurring the distinctions between state and localized elites. These actors will not feature prominently here, given the specific events in question and my interest in focusing on how modern statestheir apparatuses, administrations, and cultures-function.

I employ a historical ethnographic approach, utilizing government documents at the Lesotho National Archives and largely (but not only) pertaining to the Ministry for Tourism, Sports, and Culture (MINTOUR). I examine a series of episodes arranged in rough chronological order without proposing a causal link between them; the archives are too patchy to describe a linear course of events. Instead, what follows is a series of moments (some immediately connected, others less so) in the lifespan of a development project, each offered to illuminate modes of thinking around key concepts and tensions. I contexutalize these within continental, regional, and international heritage policy and development interventions, seeking bureaucratic understandings of what heritage was worth and what it could do in the southern African politico-economic landscape of the early 1990s.

\section{POST-INDEPENDENCE TRANSFORMATIONS}

Lesotho achieved independence from Britain in 1966, but the roots of Basotho heritage arguably stretch back to the nation's progenitor Moshoeshoe I in the 1820s. ("Basotho" refers to both the citizens of Lesotho and those who identify as descendants of Moshoeshoe's state.) During a period of clashes among African leaders and expanding settler colonialism in the early nineteenth century, Moshoeshoe forged a new polity ("Basotho") from elements of other, fragmented communities. Moshoeshoe and his attendant missionaries portrayed the resulting "chiefdom of chiefdoms" as a triumph of diplomacy over brutality. ${ }^{38}$ His capital on the flattopped mountain Thaba Bosiu ("Mountain of Night") became the center of gravity for this new organization (Figure 2). Contemporary observers and historians alike

$\overline{{ }^{38} \text { Eldredge } 1993,26,29,46 .}$ 


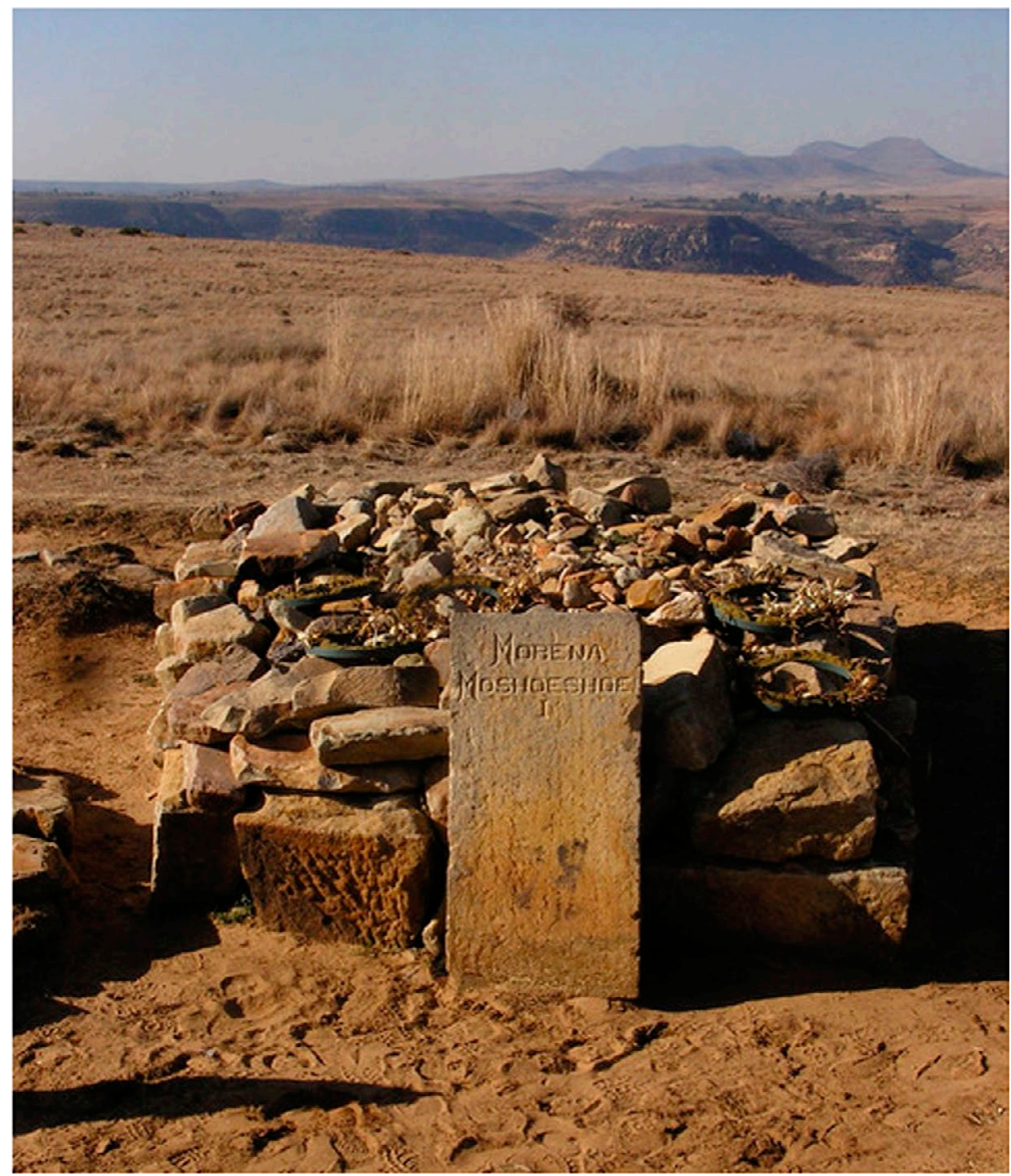

Figure 2. Grave of Moshoeshoe I on Thaba Bosiu (Image CC0, courtesy of < source of photo).

maintained that, while the diverse peoples who comprised Moshoeshoe's new order may have retained some sense of their pre-Basotho identity, this was sublimated within a primary association with Moshoeshoe and his nation. ${ }^{39}$ This political history and vocabulary were further mediated by missionaries and became codified into traditional leadership when Basutoland was annexed to the Cape Colony in 1871.

\footnotetext{
${ }^{39}$ Coplan and Quinlan 1997.
} 
Independence brought new legislation designed to protect Lesotho's cultural property, inspired partly by colonial administrative schemes. ${ }^{40}$ The Museums Act and Archives Act set up agencies to manage a National Museum and National Archives as two legs of a proposed national heritage tripod, the third of which was the national monument at Thaba Bosiu. ${ }^{41}$ The Historical Monuments, Relics, Fauna and Flora Act (expanded by Proclamation no. 36 of 1969) established the Protection and Preservation Commission (PPC), tasked with overseeing the management of monumental heritage, archaeology, and natural history. ${ }^{42}$

From 1970 to 1993, Lesotho experienced a series of coups by political and military figures, ${ }^{43}$ and the main opposition party (the Basutoland Congress Party [BCP]) spent much of this period in exile. In 1991, Phisoana Ramaema took over as chairman of the Military Council, which had ruled since 1986, and was pressured to comply with structural adjustment requirements to sustain the flow of international development aid for famine relief, health care, and infrastructure building. ${ }^{44}$ Ramaema facilitated the transition to civilian rule in 1993 with the handover to a newly elected BCP government. This was temporarily deposed through another military coup in 1994 and reinstated in 1995, remaining in power until a leadership split in 1997. The archival material discussed here begins in 1989 and spans the terminal years of the Military Council, the installation of the BCP, and the disruptions of the 1994 coup; ${ }^{45}$ throughout, a corps of bureaucrats continued to propose and debate heritage values.

\section{HERITAGE AS AMALGAM}

These years saw members of Lesotho's cultural bureaucracy engaged in continental and regional debates over preserving African cultural property while developing a national portfolio of heritage projects. Government representatives participated in international initiatives such as the Southern African Development Coordination Conference, which was focused on promoting economic development and reducing dependence on apartheid South Africa, and contributed to the formation

\footnotetext{
${ }^{40}$ Gill 2015.

${ }^{41}$ Museums Act, No. 29, 1967; Archives Act, No. 42, 1967; "Ministry of Tourism, Sports, and Culture Staff Training Programme for Culture Sections," reprinted in N. Khitsane to Planning of the Ministry for Tourism, Sports, and Culture (MINTOUR), 2 August 1991, file TSC/7/3-4, 89-92, Lesotho National Archives (LNA). The National Museum has yet to materialize fully.

${ }^{42}$ Historical Monuments, Relics, Fauna and Flora Act, No. 41, 1967.

${ }^{43}$ Thaba Bosiu was the site of (failed) flagship agricultural development scheme under the authoritarian government of the early 1970s, setting the stage for local disillusionment with top-down international aid schemes. Aerni-Flessner 2018a, 194-95.

${ }^{44}$ Rosenberg and Weisfelder 2013, 449.

${ }^{45}$ Lesotho's monarchy was in disarray (and frequently in exile) during much of this period. While the royal family almost certainly have their own theorizations of Thaba Bosiu as heritage, the distance of the monarchy from governmental decision making regarding the site during the period covered here means that it is not a major actor within this discussion.
} 
of the Oral Traditions of Southern Africa Association. ${ }^{46}$ Locally, members of MINTOUR facilitated events like art and dance competitions (including raising funds for these activities from major local businesses like Fraser's trading stores); establishing steering committees on the use of traditional medicines and their intersection with modern health care; and establishing an official orthography for Sesotho as a national language. ${ }^{47}$ MINTOUR's activities and correspondence reflect concern with preserving Sesotho oral traditions, securing intellectual property protections, and connecting cultural practices with pressing social issues like health care and women's rights. ${ }^{48}$

By 1991, however, concerns that these activities did not amount to a coherent heritage policy prompted efforts to articulate one. Director of Sports and Culture A.M. Motaung wrote a policy proposal on cultural heritage, offering insight into how heritage was debated and implemented in government. Motaung defined culture as both an inheritance and a vehicle for socioeconomic empowerment, requiring a multidisciplinary policy to support it in public life. This policy should address a vision of Basotho culture as a balancing act between what Motaung saw as the amalgam and the open society. The amalgam idea resonates with the inheritances of Moshoeshoe's state: that Sesotho (as a shorthand for culture in Lesotho) was "forged in the crucible of adversity and diversity," ${ }^{9}$ connected to the merging of other peoples in the past. Sesotho-as-amalgam had boundaries, reaffirming where Sesotho began and other cultures ended, but these boundaries should not prevent Sesotho from remaining open to ideas from a wider, changing world. This is significant given Lesotho's long history of transnationalism, represented by both migrant labor and pan-Africanist thought that circulated via relatively porous borders. ${ }^{50}$

In his proposal of the amalgam as a conceptual framework, Motaung's vision walked a line between nationalism and humanism, inflected by an awareness of Lesotho's political and economic climate. Amidst the rule of a Military Council suspected of murdering its critics and precipitating widespread violence and economic disenfranchisement, his policy suggestions included supporting laws ensuring greater freedoms of speech and civil liberties. Cultural monuments (including Thaba Bosiu) represented dynamic symbols that could be harnessed

\footnotetext{
46"Conference on Cultural Co-Operation in the SADCC Region (25-28 November 1991), Final Report, undated, file TSC/7/3-4, 89-92, LNA; Mokitimi to MINTOUR, Memorandum on Oral Traditions of Southern Africa, 27 September 1989, file TSC/7/3-4, 89-92, LNA.

${ }^{47}$ A. M. Motaung to Manager, Frasers, 31 March 1992 file TSC/7/3-4, 89-92, LNA; Ntholi to M. Damane, 16 May 1990, file TSC/7/3-4, 89-92, LNA; M. Damane to A. M. Motaung, 21 October 1991, file TSC/7/3-4, 89-92, LNA.

${ }^{48}$ Lesotho appears to have contributed funds toward only a small fraction of the international initiatives to which it was a party, privileging work on oral traditions and their protection; N. Khit'sane to PS Tourism, 4 December 1992, file TSC/7/3-4, 89-92, LNA.

${ }^{49}$ A. M. Motaung, "Policy on Culture," received 28 May 1991, 2, file TSC/7/3-4, 89-92, LNA.

${ }^{50} \mathrm{Cf}$. Aerni-Flessner 2018b.
} 
toward this vision, reminding people of a Sesotho heritage without "social fences," which still existed but was "daily being frayed at the seams." ${ }^{51}$ Monumental heritage was a vital resource in mobilizing culture to combat social ills.

Motaung also suggested investigations into the "historical foundations of Basotho," utilizing "all available tools," including oral traditions, documentary sources, and scientific techniques. ${ }^{52}$ As mentioned above, though, Sesotho language and oral culture were defining features of MINTOUR's activities. Ntsema Khit'sane, appointed curator of the (speculative) National Museum but responsible for additional roles in the ministry, supported hosting working groups on oral traditions in Lesotho. Mosebi Damane, MINTOUR's official historian, championed a campaign to standardize and promote a national orthography for Sesotho.

It is worth noting Damane's significance in Lesotho's cultural policy and history. Born in 1919, Damane taught secondary school history for over 30 years while also earning degrees from the University of South Africa, the School of Oriental and African Studies, and the Sorbonne. Damane joined the Department of History at the National University of Lesotho (NUL) in 1973 and produced numerous publications on Lesotho's history and literature. His status as Lesotho's preeminent historian was affirmed by numerous invitations to deliver the prestigious Moshoeshoe's Day speech to the nation. ${ }^{53}$ Damane was in his seventies when the Thaba Bosiu Project began, and he never saw it completed (he died in 1996), but his input illustrates the different understandings of history, stakeholder involvement, and living culture that emerged during the project, as well as the perspective of an elite situated at the intersection of academic expertise, civic responsibility, and bureaucratic accountability.

Concerns that heritage related to larger sociopolitical issues were further reflected in a 1991 proposal to UNESCO's newly launched Participation Programme aimed at providing emergency assistance to member states and non-governmental organizations. ${ }^{54}$ The proposal, ${ }^{55}$ drawn up by the Culture Committee of the Lesotho National Commission for UNESCO (of which Motaung, Khit'sane, and Damane were members), requested an international safeguarding campaign for the heritage of living culture in Lesotho, which would consist of "conscientization seminars" and an "aggressive cultural awareness campaign." 56 The campaign aimed to combat the lingering influences of colonialism and new "foreign commerce," which had been corroding cultural values, desensitizing people to local problems like soil

\footnotetext{
${ }^{51}$ Motaung, "Policy on Culture," 6.

${ }^{52}$ Motaung, "Policy on Culture," 5.

${ }^{53}$ Rosenberg and Weisfelder 2013, 107-8.

${ }^{54}$ UNESCO, "Preparation of the Draft Programme and Budget for 1990-1991 (document 25 C/5)," Director General (DG)/Note/89/1, https://unesdoc.unesco.org/ark:/48223/pf0000218904?posInSet= 3\&queryId=79fcbca0-64cd-4fbb-a7b1-3d25b17bfa11 (accessed 5 August 2019).

${ }^{55}$ UNESCO Participation Programme 1990-1991, detailed description of request from Lesotho National Commission for UNESCO, undated, 3, file TSC/7/3-4, 89-92, LNA.

${ }^{56}$ UNESCO Participation Programme 1990-1991.
} 
erosion and unemployment. There is much to unpack here, but, for the moment, it is worth noting the proposal's insistence that rejuvenating an interest in Sesotho culture and history would galvanize the public to engage more actively with socioeconomic development schemes.

\section{STRATEGIC PRIORITIES}

In September 1990, MINTOUR formally (and successfully) approached the United Nations Development Programme (UNDP) to fund a seminar on the "preservation and presentation of the cultural heritage of Lesotho." 57 This was a forward planning exercise for rehabilitating Thaba Bosiu and opening it for tourism, and articulated the visions of bureaucrat-intellectuals and international experts for the site's significance and management. The seminar took place in February 1991 and was largely organized by the working committee on Thaba Bosiu's restoration and preservation-including Damane, Motaung, and Khit'sane-with financial support from the UNDP, UNESCO, and the West German government. ${ }^{58}$ The committee envisioned the Thaba Bosiu Project as a substantial collaborative effort, involving other Basotho intellectuals and NUL faculty as well as traditional and community leaders local to the mountain. The project was to be a model for managing historical and archaeological sites in Lesotho, and, as such, the working committee envisioned input from a team of foreign consultants (supplied by UNESCO) specializing in site conservation, archaeological survey and excavation, and site interpretation-fields in which skill was lacking locally (see below). However, the local seminar participants (including the working committee and intellectuals like NUL professor David Ambrose) had specific ideas about how the project should proceed.

Seminar participants were adamant that collective and individual folk memory play a major role in rehabilitating Thaba Bosiu. The actual extent of the monument was also debated: did it only cover the mountaintop (where the bulk of Moshoeshoe's dwellings were located) or did it include the adjoining landscape where historic battles were fought and which may contain other significant sites? Both at the seminar and once the project got underway, Damane was a major proponent of the latter, broader definition of the monument, especially in light of historically significant burials and oral histories in the area. This more expansive view prevailed and facilitated the discussion of a range of visitor offerings, including a site museum, hotel, and interpretive signage.

\footnotetext{
57"Project for the Preparation of a National Seminar on Preservation and Presentation of the Cultural Heritage of Lesotho," United Nations Development Programme (UNDP) to L. Tuoane, 2 October 1990, file TSC/7/3-4, 89-92, LNA.

58“Summary of National Seminar on the Preservation and Presentation of Thaba-Bosiu and the Lesotho Cultural Heritage," enclosed in document from the UNDP to L. Tuoane, 25 March 1991, file TSC/7/4-5, LNA.
} 
The UNESCO consultants, including archaeologist Barry Jones of the University of Manchester, Christoph Ruger of the West German Rheinisches Landesmuseum, and French architectural restorer Jacques Verity, were firm that there should be minimal invasive or reconstructive intervention at the site. These specialists agreed with other seminar participants that, owing to the site's spiritual significance (see below), "any presentation programme should tend towards preservation rather than reconstruction." 59 The archaeological program they outlined consisted primarily of walking survey, aerial photography, photogrammetry, and detailed mapping. Excavation and restoration were not foregone conclusions but would only be determined pursuant to results of these non-invasive steps. Later in the project, though, excavation would rise higher on the agenda, and this plan would be heavily revised.

The consultants also recommended against building an on-site cultural villagean element initially recommended by the Lesotho Tourist Board (LTB) and aimed at providing a wider range of visitor experiences, including restaurants, conference facilities, and living heritage demonstrations. Many of the specialist recommendations emphasized the need to make any reconstruction and visitor facilities as "discreet as possible" since the "attention of the visitor should be focused exclusively" on the hill fort itself. ${ }^{60}$ The cultural village, it was believed, would detract from this goal. This suggestion chimed with earlier points about emphasizing the embeddedness of the hillfort in the wider landscape. However, the cultural village - its existence and economic viability - ultimately represents a tension between conceptions of the socio-economic value of Basotho heritage.

\section{CULTURE, CASINOS, AND CAPITAL}

These tensions were not between international consultants and local sensibilities but, rather, between competing understandings of southern Africa's (especially South Africa's) tourism industry. While international tourism to South Africa waxed and waned with major violent episodes in the struggle against apartheid and the National Party (NP), ${ }^{61}$ a major focus of domestic tourism from the 1970s was an industry of casino resorts in areas beyond direct NP control. Independent nations like Lesotho and Swaziland and, eventually, South African Bantustans (partially self-governing "homelands" designed to concentrate black ethnic groups) attracted a hospitality industry offering gambling and other vices to (mostly white) South Africans away from the NP's puritanical legislation. ${ }^{62}$ Multinational corporations like the Holiday Inn Group and Sun International competed to open resorts in Bantustans like Transkei and Bophuthatswana and in Lesotho's capital, Maseru.

\footnotetext{
59“Summary of National Seminar."

60"Summary of National Seminar."

${ }^{61}$ Grundlingh 2006, 105-6.

${ }^{62}$ Grundlingh 2006, 117.
} 
By the mid-1980s, Sun International owned two hotel-casinos in Maseru, one of which was downgraded to a hotel by the end of the decade. ${ }^{63}$

The 1991 UNDP's Project Document for Thaba Bosiu acknowledges this history, describing Lesotho's cultural and tourism industry as "underdeveloped" and declining. ${ }^{64}$ According to the report, Lesotho's share of the gambling market was shrinking, losing ground to homeland casino-hotels, and struggling to attract nature tourism. Lesotho's Fourth Five Year Development Plan (1986/7-1990/1) articulated the necessity of expanding its natural and cultural tourism industry through strategies like strengthening human and administrative capacity, improving the quality and quantity of infrastructure, and shifting industrial priorities away from gambling. These priorities were echoed broadly in the national seminar described above. The government's goals for the Thaba Bosiu Project, then, included nothing short of catalyzing a new, cohesive tourism apparatus and transforming Lesotho's tourism industry from one focused on gambling to one premised on a completely different notion of value.

This undertaking was wholly supported by the LTB, a parastatal established in 1984 to pursue programs for the tourism sector and coordinate private sector hospitality initiatives. In 1990, the LTB commissioned a technical and economic feasibility study for establishing a cultural village at Thaba Bosiu. ${ }^{65}$ The cultural village was rejected at the above seminar, but the LTB's mandate to work independently on this project came partly from government plans (beginning in 1977) to develop visitor facilities at the monument. In the LTB report, the cultural village was envisioned as a juxtaposition of the traditional with the modern, aimed at Basotho and foreign tourists seeking comfort and a specifically Basotho experience. A village complex consisted of a lodge with a restaurant and bar, residential buildings constructed to resemble Basotho rondavels (round huts), a conference center, a "traditional village," a botanical and zoological compound, and an open air court for playing the game morabaraba. The facilities would support activities like pony trekking, the demonstration of traditional crafts, bird-watching, dances, weddings, and a museum. Architecturally, and contrary to recommendations from the Thaba Bosiu seminar, the LTB study suggested a "simple but pleasing compromise between the west [sic] and sesotho [sic]." 66 The cultural village represented a new kind of resort, centered on Basotho history and culture but with elements that would feel comfortable for Western visitors.

One of the loudest voices of dissent from this plan was the 'Moho Museum of Art and History, which argued that a resort-style cultural village was inappropriate. The 'Moho Museum described itself as "non-political," “dedicated to preserv[ing]

\footnotetext{
${ }^{63}$ Rogerson 1990, 350.

${ }^{64}$ UNDP Project Document, Project LES/91/004/A/01/13, file TSC/7/4-5, LNA.

${ }^{65}$ "Technical and Feasibility Study and Masterplan for Cultural Village," Planning Officer for PS MINTOUR to All Task Force and Cultural Community Members, 14 August 1991, file TSC/7/3-4, 89-92, LNA.

66"Technical and Feasibility Study."
} 
Basotho cultural/historical heritage." 67 However, its politics were unavoidable: it was founded during the 1980s (or possibly earlier) by BCP activists who were seeking to reclaim aspects of the Basotho past they felt were repressed through missionization and colonization. Despite lacking a building or facility, the UNDP saw the 'Moho Museum as a stakeholder. In a report issued on the Thaba Bosiu Project, the museum recommended that the entire program to restore Thaba Bosiu was misguided, that the monument was a natural creation of human genius, and that preservation should emphasize a return to an almost mythically pristine, precolonial (and, apparently, unpeopled) state: clearing invasive species, preventing domestic livestock from grazing, and removing people settled at the mountain's base while avoiding installing interpretive signage. The cultural village itself was particularly offensive as "merry-making is not compatible with the historical significance of Thaba Bosiu." ${ }^{68}$ Tourists should not visit the site to disport themselves but, rather, to connect with an emotional, spiritual Basotho experience.

Despite the 'Moho Museum's report being somewhat unofficial, the UNDP's resident representative Qais Noaman agreed with its recommendations. This concord frustrated the LTB and the Principal Secretary of Tourism, Sport, and Culture, O. T. Maphasa, both of whom supported the cultural village. Marginalia on copies of the UNDP's 'Moho correspondence that Maphasa and the LTB received include such comments from Maphasa as "unfortunate" next to a paragraph wherein Noaman states that the village would damage the symbolic value of the monument. In a margin note, Maphasa refers to "the so-called" museum. ${ }^{69}$

This disagreement over the cultural village speaks to a question hanging over the Thaba Bosiu Project: how to reconcile the spiritual significance of the mountaina significance derived from its historical import and its embeddedness in wider ancestral practices-with the drive to stimulate a tourism economy based on bundling culture within a larger package of resort-style offerings. Few precedents for this existed in southern Africa, where safari parks, casino-hotels, and heavily commodified African theme parks dominated the tourism market. Despite the LTB's feasibility study suggesting that some of their proposed activities at the cultural village would receive "a blessing from the living dead" (referring to the roles of ancestors in daily life), the plan to reconcile visions of Thaba Bosiu as a spiritual site with "merry-making" was seen by many as unworkable.

These conflicts point to a larger quandary: how to value heritage as a source of identity empowerment while making it economically profitable, but without being disrespectful. These questions are of course familiar to heritage scholars today, but, for bureaucrats in 1990s Lesotho planning the country's first monument,

\footnotetext{
${ }^{67}$ M. Kabi to Q. Noaman, 27 January 1992, enclosed in PS Tourism to Lesotho Tourist Board, 4 June 1992, file TSC/7/4-5, LNA.

68"Some Stray Thoughts on Thaba Bosiu as a National Monument in the Light of Environmental Protection," enclosed in Kabi to Noaman, 27 January 1992.

${ }^{69}$ Kabi to Noaman, 27 January 1992.
} 
these issues were urgent and compelling. Moreover, they indicate the difficulties of implementing southern African perspectives on the living or spiritual senses of heritage within a project whose shape and mechanics were dictated by market and technocratic forces.

\section{SHRINES AND STAKEHOLDERS}

Damane's work on the Thaba Bosiu Project provides insights into these ideas. As described above, Damane's background made him ideally placed as a bureaucratintellectual advising on the preservation of the nation's monument, while his stature positioned him to make recommendations and critiques that did not necessarily translate into programmatic action. His suggestions for how to proceed on the project frequently ran up against the strategies suggested by international consultants, not because consultants offered contradictory advice but, rather, because their proposals often failed to acknowledge information that Damane felt was vital.

A memorandum in which Damane comments on a feasibility study for restoring Thaba Bosiu illustrates this clearly. ${ }^{70}$ The documentation surrounding this exchange is incomplete and does not include the original study, although Damane references strategies such as "Cultural Village Option B" featured in background documents that the LTB prepared for their cultural village feasibility study, part of which was outsourced to TAB, a South African consultancy; Damane could be referring to a version of this study. Nevertheless, his reactions reveal his quarrels not only with the restoration strategy but also with consultants that he perceived as foreigners ill-suited to working in Lesotho.

Damane spent much of his memo identifying what he thought was incorrect historical data and disagreeing with its conclusions about the availability of materials suitable for restoring Thaba Bosiu to its nineteenth-century state. In a manner befitting a lifelong teacher, Damane corrected perceived misconceptions about the availability of thatch by offering an extensive list of places in Lesotho where thatch could be obtained. He identified cultural misunderstandings, including a false equation of Basotho house decorations (litema) with specific clans (liboko). But Damane's greatest frustration was with a section describing the incorporation of indigenous flora into the cultural village and monument. Referring to one passage, Damane wrote: "Basotho traditional doctors are no longer referred to as WITCHDOCTORS" and further vented his anger at foreign consultants with a parenthetical: “THIS SECTION SHOULD HAVE BEEN GIVEN EITHER TO DR LETSIE OR DR JONATHAN, and not an outsider." 71 While Damane expressed his support for treating Thaba Bosiu as an "educational and tourist" resource, his

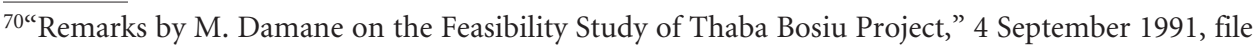
TSC/7/4-5, LNA.

71 "Remarks by M. Damane" (emphasis in original).
} 
criticisms highlight the frustrations involved in articulating a new form of visitor engagement, which necessarily drew in outside expertise and, by extension, historical and cultural misalignments.

Many of Damane's critiques of the cultural village resonate with those of the 'Moho Museum. Damane likewise believed that the mountain's significance as a shrine meant that European liquor (as opposed to Basotho-brewed joala) must not be allowed, not least because Moshoeshoe issued an interdict against the consumption of alcohol in 1854 . He also argued that the mountaintop should not be seen as a discrete, beacon-like monument but, rather, as something embedded in the larger landscape, including footpaths, cliff sides, and the valley bottom. In light of this, he wrote to his MINTOUR colleagues to voice his concern about people quarrying stones from the mountain's sides and thereby disrespecting the integrity of the site. ${ }^{72}$ These tensions between visions of monuments versus shrines are familiar ones in southern Africa, as Western-led paradigms of preserving ossified ruins have clashed with local sensibilities locating the significance of heritage places with living cultures. ${ }^{73}$

These concerns about respect for and from local constituencies, as well as the location of Thaba Bosiu within a larger physical and social network, led Damane to advocate for an extensive program of community consultation. ${ }^{74} \mathrm{He}$ proposed holding a series of public fora and discussions with villages local to Thaba Bosiu, their chiefs, church leaders, and secondary school teachers and pupils. His belief in the need to obtain buy-in for the project from local constituencies led Damane to proclaim: "Any work of development succeeds in direct proportion with consultation with local people." 75 A statement of this sort from a management elite like Damane elaborates on the relationship between elites and the grassroots, illustrating how the latter was a major concern in opening Thaba Bosiu to a wider public.

However, expanding upon Damane's views and placing these within a broader context of authority in Lesotho public life illustrates the complexities of his position on public rights to heritage. One of Damane's chief worries (as demonstrated by his criticisms of quarrying) was that the Basotho public needed to be reminded of their obligations toward national patrimony and to Moshoeshoe's legacy, in particular. Basotho were the stewards of this heritage, but they had forgotten what stewardship entailed; we see echoes of Motaung's rationale for Lesotho's heritage policy. Damane's call for community consultation was born partly from this perspective, treating Thaba Bosiu as national (rather than local) heritage, which led to treatments of local people as being answerable to higher traditional or state authority-to elites.

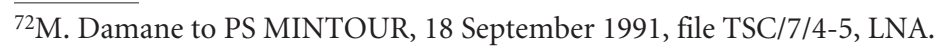

${ }^{73}$ Ndoro 2001.

${ }^{74}$ M. Damane to PS MINTOUR, 20 May 1992, file TSC/7/4-5, LNA.

${ }^{75}$ Damane to PS MINTOUR, 20 May 1992.
} 
A good illustration of this hierarchy can be found in Damane's suggested mechanisms for monitoring damage to Thaba Bosiu. In 1993, once the project had gotten underway, Damane wrote to the MINTOUR director to update him on the current status of reported trespassing or illicit activity on the mountain. ${ }^{76}$ Damane explained that there was currently a guide operating in the area, a Mr M. Moshoeshoe, who was described as a "great-great descendant" of Moshoeshoe I, and that the guide "will regard it as his moral duty" to report damage to the ruins, given the site's "cultural and emotional significance."77 However, Damane noted that there were no reports to the Basotho royal representative responsible for monitoring the mountain's upkeep. Moreover, Damane reported that people known to Mr Moshoeshoe have been allowed to "tamper with" the ruins with the guide's knowledge. It was also under Mr Moshoeshoe's watch that Damane noticed the presence of numerous empty beer cans at the site, violating the prohibitions against alcohol consumption. Damane's solution to this inadequate reporting was to "persuade" Mr Moshoeshoe to take all "sacreligious" activities to the royal representative, and, failing this, the matter would be escalated to a ministerial level.

Damane championed community consultation, but he located this consultation within traditional and state authority. While acknowledging the emotional and spiritual significance of Thaba Bosiu to all Basotho, and thereby positioning all Basotho as stakeholders, Damane also believed that people local to the site needed to be reminded of these obligations. Government and chiefly elites were the best suited to this task. Returning to the conceits of neoliberal, grassroots heritage management, we see a tension between Damane's position and the suggestion that people local to African heritage sites have always been management experts. Importantly, though, Damane does not actually describe a lack of management knowledge but, rather, a disconnection from a form of respect that he traces back to the beginning of the Basotho nation: directives from Moshoeshoe I had already provided management guidelines for spiritual sites such as do not consume alcohol and do not tamper with places honoring ancestors. The problem was rather that these guiding principles were fading from public consciousness. This echoes Motaung's policy position described earlier: the present generation of Basotho were pushed and pulled by forces of conflict and globalization such that they had become estranged from these earlier teachings.

Damane's input into the management process, written from the position of a bureaucrat-intellectual with expertise in history, demonstrates the nuances of how an elite actor viewed community engagement. The public were a rightful stakeholder, with stewardship obligations rooted in a cultural memory that needed to be revitalized, and this revitalization was within the government's power to bring about. Moreover, public engagement was not an alternative to traditional or state authority; it had to be located within that authority to become effective.

\footnotetext{
76M. Damane to A. M. Motaung, 7 June 1993, file TSC/7/4-5, LNA.

${ }^{77}$ Damane to Motaung, 7 June 1993.
} 
That said, throughout the project, government representatives were engaged in the process of carefully justifying their authority while qualifying their capacity. This was part of a longer-term vision for Lesotho's cultural property, one that rested on distinguishing between the government's technical ability and its heritage expertise.

\section{DEMONSTRATING INCAPACITY}

Technical capacity for heritage management in Lesotho was a substantial part of the Thaba Bosiu Project and was built into the project's staffing and work plan. Ultimately, such technical capacity emphasized archaeological and architectural elements (especially excavation) over living heritage, despite the priorities stated at the Thaba Bosiu seminar. ${ }^{78}$ As per the project's funding agreement, the UNDP and UNESCO agreed to provide a chief technical advisor, consultants in archaeology, architectural restoration, and museology as well as three UN volunteers specializing in archaeology, architecture, and landscape planning. ${ }^{79}$ The government would provide understudies to shadow the UN experts, a national project coordinator, a historian, and a museum curator. Training Basotho specialists in archaeology and restoration was a compulsory part of the work on Thaba Bosiu, and it factored into the timelines for the project's completion.

Lesotho's dearth of qualified heritage managers and infrastructure was central to the project not only as a justification for investing in the country's nascent tourism industry but also as a way of highlighting where this shortage would have widerreaching impacts. The Thaba Bosiu seminar drew attention, in particular, to the Lesotho Highlands Water Project (LHWP). Launched in 1986, the LHWP was the product of a binational treaty between South Africa and Lesotho aimed at creating a water delivery system that would allow Lesotho to sell water to South Africa while possibly generating in-country electricity. The LHWP consisted of five mega-dams (a sixth was added in 2007); construction for the first of these got underway in 1991, the same year as the seminar, and had necessitated an archaeological impact assessment for the dam's catchment. This impact assessment was conducted by South African archaeologists as none were available in Lesotho, ${ }^{80}$ and the lack of national capacity for addressing a further four massive heritage mitigation programs was on the minds of participants in the Thaba Bosiu seminar.

At the seminar, government representatives used the LHWP and other development projects to underscore the need to strengthen Lesotho's National Monuments Register, the PPC responsible for protecting properties on the register, and the PPC staff in fields beyond tourism. This included providing technical skills in archaeological excavation and site conservation, which the UNDP and UNESCO agreed

\footnotetext{
${ }^{78}$ A. D. Igirgi, "Work-Plan for Archaeological Works," 1 October 1993, file TSC/7/4-5, LNA.

${ }^{79}$ UNDP Project Document, Project LES/91/004/A/01/13.

${ }^{80}$ Lewis-Williams and Thorp 1989.
} 
to provide for Thaba Bosiu as a test case of how such an arrangement would work. The ability to create plans for mitigating and managing different kinds of heritage and the legal apparatuses for enforcing these were thus crucial long-term gains envisioned from the Thaba Bosiu Project and the initiatives it would galvanize.

Recall, though, that the seminar also saw Basotho bureaucrat-intellectuals displaying their extensive knowledge of Lesotho oral traditions and history as well as their own visions for how to present complex spiritual sites like Thaba Bosiu. Requests for skills transfer were not the same as an admission of government ineptitude. Instead, we should see this as government representatives deliberately drawing a line between describing lack of technical management capacity and expertise in living heritage. One could read this as administrators speaking the language of Euro-American heritage technocracy. The main point, though, is that we see bureaucrats engaged in complicated dance of demonstrating or performing incapacity while also displaying specific kinds of knowledge about cultural property for international funders.

I do not suggest that any deception, corruption, or otherwise unethical behavior was at work; quite the opposite. Demonstrating incapacity was equally about performing specific forms of knowledge and visions for the future contingent on building new bodies of expertise, which demanded highlighting where such expertise was lacking. The challenge was demonstrating this lack convincingly without diminishing the case for authority in other realms like oral history and historical research, a balance that technocratic frameworks for heritage development often fail to observe. ${ }^{81}$ The result, though, was a tradeoff between living heritage priorities and technical training. The project's scheme stressed archaeological and architectural work, including oral historical studies as minor components. This was partly due to the division of labor proposed by the government representatives, but also to the fact that oral traditions did not fit easily into the international experts' management strategies or funding plan. Living heritage was given lower priority and fewer resources, and it ultimately faded from view.

\section{CONCLUSION}

This view of the state as a "bundle of practices" offers insights into how states and their elites made knowledge about, and developed agendas for, cultural property. We have seen how in the early 1990s government policies were reasoned and legislated in the context of contemporary political imperatives, emphasizing living heritage as a form of pan-African, post-independence culture and major intellectual property concern in a rapidly globalizing world. While the disjunct between government priorities and the expertise provided by international consultants is now a familiar trope in heritage studies, ${ }^{82}$ a consequence of this in Lesotho was that

\footnotetext{
${ }^{81}$ Lafrenz Samuels 2018.

${ }^{82}$ Lafrenz Samuels 2018.
} 
state agendas were shelved because they were supported by neither consultant ability nor international management frameworks. Living heritage studies were part of the initial Thaba Bosiu Project, but the technical expertise offered by the UNDP related primarily to built heritage conservation; the latter became a focus of the development plan, and the former did not. After more than 20 years and the implementation of the CSICH, UNESCO funded an intangible heritage assessment of Thaba Bosiu, fulfilling the recommendations of the Thaba Bosiu Project. ${ }^{83}$ As of 2003, intangible heritage has been part of UNESCO's language and management frameworks and is therefore now within its remit to support, unlike in the 1990s.

A related process was at work in Lesotho's early desire for a new tourism industry. Consultants and bureaucrats struggled to define and actualize this because there were few precedents and thus few resources to draw upon, in addition to the clashes between different visions for this tourism strategy. It is worth interrogating whether or how these same processes have played out over the last decades of evolving global heritage management policies in African contexts and elsewhere and what these reveal about how states' heritage epistemologies developed historically in relation to international frameworks. ${ }^{84}$

It is also worth revisiting how a lack of expertise has been defined historically. We have seen how the government's ability to demonstrate incapacity was part of a case for greater international support. Incapacity was not the same as a lack of vision for or knowledge about cultural property but, rather, a commentary on a desire to enhance technical ability. We see a similar process at work in later calls for funding heritage capacity building in development projects, as with the 2008-12 heritage salvage program associated with Lesotho's Metolong Dam. ${ }^{85}$ At Thaba Bosiu and Metolong, we see a focus on strengthening individual, human capacity that would translate into institutional capacity. This latter has yet to materialize fully; ${ }^{86}$ space does not permit speculation on why Lesotho still lacks a robust heritage industry. The main point, though, is that too often heritage development initiatives in Africa aim to foster the transfer of local skills and are unaware of longer histories of exactly the same sorts of interventions, thereby continuing to focus on individuals rather than institutional structures as the agents of sweeping change. The process is thus repeated and the same outcomes reproduced, while states' incapacities are easily conflated with a lack of vision.

This split focus on local people as capacitated and states as incapacitated speaks to a larger need to interrogate how relationships among government agents, local communities, and scholars of cultural property are conceptualized. Damane's position toward public participation illustrates the nuances of bureaucratic elite

\footnotetext{
${ }^{83}$ UNESCO, Final Narrative Report, Project LSO-01118, 9 February 2018, https://ich.unesco.org/doc/ download.php?versionID=47425 (accessed 5 August 2019).

${ }^{84}$ Cf. Ndoro and Wijesuriya 2015.

${ }^{85}$ Arthur, Mohapi, and Mitchell 2011.

${ }^{86}$ King and Arthur 2014.
} 
relationships to local communities. His priorities aimed to mobilize people toward the dream of a national community, focusing on local needs insofar as he wanted to reach all aspects of local life (church, school, traditional authority) with his message. For him, the residents of the Thaba Bosiu area were not ignorant about site preservation; their innate cultural resources for preservation had been disrupted. Of course, this was a nationalistic vision, and the Thaba Bosiu Project was rife with anti-local suggestions (for example, the 'Moho Museum's recommendation to displace residents from the mountain's base) and mechanisms for excluding local knowledge, but to characterize Damane's position only in this way misses the complexities in his thinking. This underscores important factors in evaluating the role of heritage management elites in Lesotho and elsewhere: what are their habits of reasoning, how does this relate to their bureaucratic position, and how does this set the agenda not only for policies and practices but also for the language and discourse surrounding heritage? This amounts to a call to nuance and expand how management elites are theorized in heritage studies.

That these questions receive little attention in scholarly literature is as much a product of dominant research methodologies - conceiving of local and bureaucratic knowledge as qualitatively different-as the historical tensions between state and community visions of cultural property. Where heritage scholarship derives from anthropology, the methodological toolkit available privileges a focus on small-scale, local perspectives that resonate with recent disciplinary and international policy emphases on the grassroots as necessary agents of heritage preservation. This notion is certainly a relevant and important point. However, if the neoliberalization of heritage mirrors that of governance (as Coombe argues it does), then we must ask whether our views of states as disengaged from actively thinking about cultural property mirror neoliberal ones of bureaucracies as disconnected from actively governing. ${ }^{87}$ I have argued here that governments can be compelling sites of knowledge production about cultural property-its management and its constitution-and that tracing this activity historically offers insight into domestic dynamics between the local and the state, and also into the trajectories of international networking and development strategies over time. This is a history of knowledge production that has yet to be told fully, but one that is vital for understanding the impacts of future heritage development programs, as each era of UN sustainable development actions brings new interventions and partnerships with states whose cultures and histories are often incompletely understood.

\section{BIBLIOGRAPHY}

Aerni-Flessner, John. 2018a. Dreams for Lesotho: Independence, Foreign Assistance, and Development. Notre Dame, IL: University of Notre Dame Press.

$\overline{{ }^{87} \text { Coome } 2012 .}$ 
Aerni-Flessner, John. 2018b. "Passports, Citizenship, Residency and Asylum: The Meanings of Decolonisation in Lesotho." Journal of Imperial and Commonwealth History 46: 758-83.

Arthur, Charles, Moleboheng Mohapi, and Peter Mitchell. 2011. "Archaeology and Dam Projects in Lesotho." Conservation and Management of Archaeological Sites 13: 231-52.

Bayart, Jean-Francois, Stephen Ellis, and Beatrice Hibou. 1999. The Criminalisation of the State in Africa. Oxford: James Currey.

Chalfin, Brenda. 2010. Neoliberal Frontiers: An Ethnography of Sovereignty in West Africa. Chicago: University of Chicago Press.

Chirikure, Shadreck, Webber Ndoro, and Janette Deacon. 2018. "Approaches and Trends in African Heritage Management and Conservation." In Managing Heritage in Africa: Who Cares?, edited by W. Ndoro, S. Chirikure, and J. Deacon, 2-21. New York: Routledge.

Clapham, Christopher. 1996. Africa and the International System: The Politics of State Survival. New York: Cambridge University Press.

Coombe, Rosemary J. 2012. "Managing Cultural Heritage as Neoliberal Governmentality." In Heritage Regimes and the State, edited by R. F. Bendix, A. Eggert, and A. Peselman, 375-88, 2nd ed. Gottingen: Universitatsverlag Gottingen.

Cooper, F. 2002. Africa since 1940: The Past of the Present. New York: Cambridge University Press.

Coplan, David B., and Tim Quinlan. 1997. "A Chief by the People: Nation Versus State in Lesotho.” Africa 67: 27-60.

Eldredge, Elizabeth A. 1993. A South African Kingdom: The Pursuit of Security in Lesotho. Cambridge, UK: Cambridge University Press.

Ferguson, James. 2006. Global Shadows: Africa in the Neoliberal World Order. Durham, NC: Duke University Press.

Ferguson, James, and Akhil Gupta. 2002. "Spatializing States: Toward an Ethnography of Neoliberal Governmentality.” American Ethnologist 29: 981-1002.

Gill, Stephen. 2015. Museums Lesotho: Building upon the Legacy: An Inquiry into the Idea and Reality of a National Museum in Lesotho. Morija: Morija Museum and Archives.

Grundlingh, Albert. 2006. "Revisiting the 'Old' South Africa: Excursions into South Africa's Tourist History under Apartheid." South African Historical Journal 56: 103-22.

Jopela, Albino de Jesus. 2017. "The Politics of Liberation Heritage in Postcolonial Southern Africa with Special Reference to Mozambique." PhD dissertation, University of the Witwatersrand, Johannesburg, South Africa.

Keitumetse, Susan O. 2011. "Sustainable Development and Cultural Heritage Management in Botswana: Towards Sustainable Communities.” Sustainable Development 19: 49-59.

Keitumetse, Susan O. 2014. "Cultural Resources as Sustainability Enablers: Towards a CommunityBased Cultural Heritage Resources Management (COBACHREM) Model.” Sustainability 6: 70-85.

Keitumetse, Susan O. 2016. African Cultural Heritage Conservation and Management: Theory and Practice from Southern Africa. Cham: Springer. 
Keitumetse, Susan O., Geoffrey Matlapeng, and Leseka Monamo. 2007. "Cultural Landscapes, Communities, and World Heritage: In Pursuit of the Local in the Tsodilo Hills, Botswana." In Envisioning Landscape: Situations and Standpoints in Archaeology and Heritage, edited by D. Hicks, L. McAtackney, and G. Fairclough, 101-19. London: Springer.

King, Rachel, and Charles Arthur. 2014. "Development-Led Archaeology and Ethics in Lesotho." Azania: Archaeological Research in Africa 49: 166-83.

Lafrenz Samuels, Kathryn. 2018. Mobilizing Heritage: Anthropological Practice and Transnational Prospects. Gainesville: University Press of Florida.

Lewis-Williams, J. David, and Carolyn Thorp. 1989. “Archaeology: Lesotho Highlands Water Project Environmental Study," report of an assignment comprising part of the Sixth European Development Fund Project no. 6200.16.33.001. London: Environmental Resources.

Li, Tania Murray. 2007. The Will to Improve: Governmentality, Development, and the Practice of Politics. Durham, NC: Duke University Press.

Meskell, Lynn. 2018. A Future in Ruins: UNESCO, World Heritage, and the Dream of Peace. New York: Oxford.

Mkandawire, P. Thandika, and Charles C. Soludo. 2003. "Introduction: Towards the Broadening of Development Policy Dialogue for Africa." In African Voices on Structural Adjustment, edited by P. T. Mkandawire and C. C. Soludo, 1-16. Trenton, NJ: Africa World Press for CODESIRA.

Ndoro, Webber. 2001. "Your Monument, Our Shrine: The Preservation of Great Zimbabwe." PhD dissertation, Uppsala University, Uppsala, Sweden.

Ndoro, Webber. 2003. "Traditional and Customary Heritage Systems: Nostalgia or Reality? The Implications of Managing Heritage Sites in Africa." In Linking Universal and Local Values: Managing a Sustainable Future for World Heritage, edited by E. de Merode, R. Smeets, and C. Westnik, 81-84. Paris: UNESCO.

Ndoro, Webber, and Gilbert Pwiti. 2004. "Heritage Management in Southern Africa: Local, National and International Discourse." In Heritage, Museums and Galleries: An Introductory Reader, edited by G. Corsane, 154-68. London: Routledge.

Ndoro, Webber, and Gamini Wijesuriya. 2015. "Heritage Management and Conservation: From Colonization to Globalization.” In Global Heritage: A Reader, edited by L. Meskell, 131-49. London: Wiley Blackwell.

Peterson, Derek R.. 2015. "Introduction: Heritage Management in Colonial and Contemporary Africa." In The Politics of Heritage in Africa: Economies, Histories, and Infrastructures, edited by D. R. Peterson, K. Gavua, and C. Rassool, 1-36. Cambridge, UK: Cambridge University Press.

Rogerson, Christian M. 1990. "Sun International: The Making of a South African Tourismus Multinational." GeoJournal 22: 345-54.

Rosenberg, Scott, and Richard Weisfelder. 2013. Historical Dictionary of Lesotho, 2nd ed. Plymouth: Scarecrow Press.

Tsing, Anna. 2001. “Inside the Economy of Appearances.” In Globalization, edited by A. Appadurai, 155-88. Durham, NC: Duke University Press. 